OOPEN ACCESS

International Journal of Advanced Economics

P-ISSN: 2707-2134, E-ISSN: 2707-2142

Volume 3, Issue 4, P.No. 97-105, August 2021

DOI: 10.51594/ijae.v3i4.248

Fair East Publishers

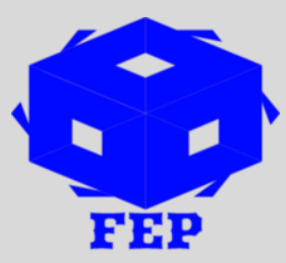

Journal Homepage: www.fepbl.com/index.php/ijae

\title{
VALUE ADDITION ANALYSIS OF LOCUST BEANS (PARKIA BIGLOBOSA) IN AKOKO NORTHWEST LOCAL GOVERNMENT AREA OF ONDO STATE, NIGERIA
}

\author{
J.O. Ijigbade ${ }^{1}$, O.A. Aturamu ${ }^{2}$, \& F.O. Osundare ${ }^{3}$ \\ ${ }^{1}$ Department of Agricultural Technology, Rufus Giwa Polytechnic Owo, Ondo State, Nigeria \\ ${ }^{2}$ Department of Agricultural Science and Technology, Bamidele Olumilua University of \\ Education, Science and Technology, P.M.B 250, Ikere-Ekiti, Ekiti State, Nigeria. \\ ${ }^{3}$ Department of Agricultural Economics and Extension, Ekiti State University, Ado Ekiti, \\ Nigeria
}

*Corresponding Author: Ijigbade, J.O

Article Received: $15-08-20$

Accepted: 25-08-21

Published: $30-08-21$

Licensing Details: The author retains the right to this article. The article is distributed under the terms of the Creative Commons Attribution-NonCommercial 4.0 License (http://www.creativecommons.org/licences/by-nc/4.0/) which permits non-commercial use, reproduction, and distribution of the work without further permission provided the original work is attributed as specified on the Journal open access page.

\section{ABSTRACT}

The study investigated the value addition of locust beans in Akoko Northwest LGA of Ondo State. Primary data were collected for the study and a multi-stage sampling technique was employed to select the respondents using a well-structured questionnaire. Descriptive statistics and gross margin analysis were employed to analyse the data. The result revealed that majority $(60.00 \%)$ and $(66.70 \%)$ of the producers and processors respectively were above 50 years of age, whereas about $90.00 \%$ of the marketers were below 50 years of age. Similarly, majority $(91.10 \%)$ of the respondents were married female with about $75.60 \%$ having one form of education or the other. The producers made an average net income of $\$ 21,843.97$ at a selling price of $\$ 635.24$ while the processor made a net income of $\$ 16,648.02$ at a selling price of $\$ 46.90$ per $\mathrm{kg}$ and the marketer made a net income of $\$ 22,950.00$ at a selling price of $\$ 1,200.00$ per $\mathrm{kg}$. This implies that while a producer made a gain of 52 kobo on every 1 invested in the business, the processor and marketer made 21 and 24 kobo respectively on every 1 invested in the business in the area. Result further revealed that while lack of modern technology was the first and most severe problem of the producers, lack of capital was attested to be the most militating problem of the processors and lack of organised market was the most militating challenge of the marketers.

Keywords: Value Addition, Locust Beans, Costs, Returns, Gross Margin, Nigeria. 


\section{INTRODUCTION}

African locust bean (Parkia biglobosa) is a member of the leguminosae family normally found around the tropics and several towns in the savannah territories of West Africa especially in the Middle Belt and South Western area of Nigeria. It is a perennial tree legume which produces fruits from December to March and harvested in April - May with many leguminous pods each with a tough pericarp. The tree has a height ranging from 7 to $20 \mathrm{~m}$ and in some exceptional cases some might reach heights of about $30 \mathrm{~m}$, with a wide spreading umbrella-shaped crown (Teklehaimanot, 2004; Ojewumi, Omoleye and Ajayi, 2016). It can start to bear fruits from five to seven years after planting (Musa, 1991). The most important use of African locust bean is found in its seed, which is a grain legume, although it has other food and non - food uses, especially the seeds which serves as a source of useful ingredients (food condiment) for consumption (Campbell-platt, 1980). The husks and pods also serve as good food for livestock (Douglass 1996; Eka, 1980). Though efforts have been made to scientifically study the traditional processing, marketing, physical and chemical changes, as well as the micro-organisms involved in the processing of African locust bean by CampbellPlatt, (1980), Odunfa, (1981), and Babalola, (2012), there is still much to be done in the area of value addition of the produce. However, since the people of Akoko Northwest Local Government Area are not only known to depend on locust beans "Iru" for their household delicacies over the years but are also seen as the major producers and processors of the product in Ondo State, it is of paramount importance and worthwhile to carry out a study that would eventually improve the processing and utilization of the product in the area.

Value addition to agricultural products is the process of increasing the economic value and consumer satisfaction of an agricultural commodity (Babalola, 2012). Various value-adding technologies include processing and preservation techniques, dehydration and drying technology, fermentation, labelling, packaging and branding (Babalola, 2012; Adedokun, 2006). The turnover plus income from services over the cost of bought-in of materials and services are termed as gross value added (Adejumo, 2008). The annual charge of depreciation on the remainder is called net value-added. Furthermore, the excess of turnover plus the income from services over cost of bought-in of materials and services is termed value added and the annual charge of depreciation is known as an application of value added available to the owners of the enterprise in the form of retained earnings (Adejumo, 2008).

\section{Objectives of the Study}

The research aims at assessing the value addition of locust beans in Akoko North West Local Government Area of Ondo State, Nigeria.

The specific objectives are to;

i. describe the socio- economic characteristics of locust beans value addition actors in the study area.

ii. determine costs and returns to value added locust bean in the study area.

iii. identify the major constraints to locust beans value addition in the study area.

\section{RESEARCH METHODOLOGY}

\section{Study Area}

Akoko Northwest is one of the eighteen Local Governments that made up Ondo State in the Southwest Region of Nigeria. It falls within latitudes $7^{\circ} 30^{\prime}$ and $7^{\circ} 35^{\prime} \mathrm{N}$ and longitudes $5^{\circ} 43^{\prime}$ and $5^{\circ} 49^{\prime} \mathrm{E}$. The climate can be said to be subequatorial with two peaks of rainfall. The first peak comes up between April and July while the second peak comes up between late August and late October. These two peaks are marked by heavy rainfall and the mean annual rainfall 
is $1500-2000 \mathrm{~mm}$ with a relative humidity of about $75-95 \%$. Since the climate is sub equatorial, temperature could sometimes be severe. The mean annual temperature is $23-26^{\circ} \mathrm{C}$ (Adejumo, 2008). Agriculture is the major occupation in the area.

\section{Data and Sampling Techniques}

Primary data was used generally for the study while multistage sampling technique was employed to select respondents for the study. The first stage involved purposive selection of 6 towns, namely, Arigidi, Ibaham, Iyani, Ikaram, Iye and Asa in the local government area. The towns were chosen based on the prominence of locust beans in the areas. The second stage involve the selection of 5 producers, 5 processors and 5 marketers in each of the towns (communities) making a total of 90 respondents in all.

\section{Methods of Data Analysis}

Data collected were subjected to descriptive statistics and budgetary analysis. Descriptive statistics such as frequency distribution, means, charts and percentages were used to analyse the socio-economic characteristics of the respondents. Budgetary (Gross margin) analysis was used to evaluate costs and returns on locust beans enterprise by the respondents.

Gross margin will be mathematically expressed as:

$G M=P Q-\sum_{j=1}^{m} C_{j} X_{j}$

Where; GM = Farm Gross Margin, $\mathrm{P}=$ Market price of output $/ \mathrm{kg}, \mathrm{Q}$ = Quantity of output produced, processed or sold by ith locust bean value addition actor, $\mathrm{Cj}=$ Unit price of the variable input $\mathrm{j}$ incurred by ith locust bean value addition actor, $\mathrm{Xj}=$ Quantity of variable inputs $\mathrm{j}$ used by ith locust bean value addition actor, $\mathrm{m}=$ Number of variable inputs used by ith locust bean value addition actor.

\section{RESULTS AND DISCUSSION}

\section{Socio-Economic Characteristics of Actors in Locust Beans Value addition}

Table 1 display the frequency and percentage distributions of socio-economic characteristics of actors in locust beans value addition in the study area. The result revealed that majority $(60.00 \%)$ and $66.70 \%$ of the producers and processors respectively were above 50 years of age, whereas about $90.00 \%$ of the marketers were below 50 years of age. This implies that the marketers were younger and likely to be more economically active than the producers and processors in the business. Similarly, majority $(91.10 \%)$ of the respondents were married female with 6 and 10 household members. This implies that locust bean business is a female gender enterprise with available family labour for their business in the area. Also, majority (75.60\%) of the respondents had one form of education or the other. This, however, indicated that majority of the respondents were educated and will be ready to accept new innovations on the business when introduced to them. The result revealed that majority $(88.89 \%)$ of the respondents were highly experienced with over 5 years' experience in the business. It also indicated that only $26.7 \%$ of the respondents had access to credit while majority (68.9\%) were not visited by extension agents on the business. These however suggests that many of the actors will depend on their personal savings in financing the business and also lack innovative information on locust beans venture in the study area. 
Table 1

Socio-Economic Characteristics of Actors in Locust Beans Value Addition

\begin{tabular}{|c|c|c|c|c|c|c|c|c|}
\hline \multirow{2}{*}{$\begin{array}{c}\text { Actors } \\
\text { Variables }\end{array}$} & \multicolumn{2}{|c|}{ Producer } & \multicolumn{2}{|c|}{ Processor } & \multicolumn{2}{|c|}{ Marketer } & \multicolumn{2}{|c|}{$\begin{array}{c}\text { Total } \\
\text { Pooled }\end{array}$} \\
\hline & Freq. & $\%$ & Freq. & $\%$ & Freq. & $\%$ & Freq. & $\%$ \\
\hline \multicolumn{9}{|l|}{ Age } \\
\hline$\leq 30$ & 4 & 13.3 & 4 & 13.3 & 2 & 6.7 & 10 & 11.1 \\
\hline $31-50$ & 8 & 26.7 & 6 & 20 & 25 & 83.3 & 39 & 43.3 \\
\hline $51-70$ & 14 & 46.7 & 14 & 46.7 & 2 & 6.7 & 30 & 33.3 \\
\hline$\geq 70$ & 4 & 13.3 & 6 & 20 & 1 & 3.3 & 11 & 12.2 \\
\hline \multicolumn{9}{|l|}{ Gender } \\
\hline Male & 1 & 3.3 & 6 & 20 & 1 & 3.3 & 8 & 8.9 \\
\hline Female & 29 & 96.7 & 24 & 80 & 29 & 96.7 & 82 & 91.1 \\
\hline Total & 30 & 100 & 30 & 100 & 30 & 100 & 90 & 100.0 \\
\hline \multicolumn{9}{|l|}{ Marital status } \\
\hline Single & 4 & 13.3 & 2 & 6.7 & 2 & 6.7 & 6 & 6.7 \\
\hline Married & 26 & 86.7 & 28 & 93.3 & 28 & 93.3 & 82 & 91.1 \\
\hline \multicolumn{9}{|l|}{ Household size } \\
\hline$\leq 5$ & 12 & 40 & 7 & 23.3 & 8 & 26.7 & 27 & 30.0 \\
\hline $6-10$ & 14 & 46.7 & 20 & 66.7 & 20 & 66.7 & 54 & 60.0 \\
\hline$\geq 11$ & 4 & 13.3 & 3 & 10 & 2 & 6.7 & 9 & 10.0 \\
\hline \multicolumn{9}{|l|}{ Educational status } \\
\hline No formal education & 10 & 33.3 & 3 & 10 & 9 & 30.0 & 22 & 24.4 \\
\hline Primary school education & 8 & 26.7 & 23 & 76.7 & 3 & 10.0 & 34 & 37.8 \\
\hline Secondary school education & 12 & 40.0 & 4 & 13.3 & 16 & 53.3 & 32 & 35.6 \\
\hline Tertiary school education & 8 & 26.7 & 0 & 0 & 2 & 6.7 & 10 & 11.1 \\
\hline \multicolumn{9}{|l|}{ Experience (year) } \\
\hline$\leq 5$ & 4 & 13.3 & 3 & 10 & 3 & 10 & 10 & 11.11 \\
\hline$\leq 6-10$ & 19 & 63.33 & 10 & 33.33 & 17 & 56.67 & 46 & 51.11 \\
\hline $11-15$ & 3 & 10 & 11 & 36.7 & 6 & 20 & 20 & 22.22 \\
\hline$\geq 15$ & 4 & 13.3 & 6 & 20 & 4 & 13.33 & 14 & 15.56 \\
\hline \multicolumn{9}{|l|}{ Access to credit } \\
\hline Yes & 17 & 56.7 & 3 & 10 & 4 & 13.3 & 24 & 26.7 \\
\hline No & 13 & 43.3 & 27 & 90 & 26 & 86.7 & 66 & 73.3 \\
\hline \multicolumn{9}{|l|}{ Belong to Association } \\
\hline No & 15 & 50 & 27 & 90 & 22 & 73.3 & 64 & 71.1 \\
\hline Yes & 15 & 50 & 3 & 10 & 8 & 26.7 & 26 & 28.9 \\
\hline \multicolumn{9}{|l|}{ Extension agent visitation } \\
\hline Yes & 17 & 56.7 & 4 & 13.3 & 7 & 23.3 & 28 & 31.1 \\
\hline No & 13 & 43.3 & 26 & 86.7 & 23 & 73.3 & 62 & 68.9 \\
\hline Total & 30 & 100 & 30 & 100 & 30 & 100.0 & 90 & 100.0 \\
\hline
\end{tabular}

Figure 1 depicts the steps involved in the processing of edible locust beans from the fruit to the final products. The whole processes are done through traditional methods and it takes an average of 9 days to complete the process. The processing site is always noticed with an unpleasant odour with dark liquid mixed with water. The edible locust is always preserved with salt and packed in a container. It is normally sold using plantain/banana leaves but the technology has improved, marketers are now repacking the product using nylon and 
transparent plastic containers instead of leaves. The final products are sold in different sizes depending on the quantity requested by the consumers. Locust beans (Iru) forms one of the main soup ingredients in the study area. It is sometime used as proxy to meat, and without it the soup is incomplete.

\section{Steps in production of African locust beans to final edible product}

Raw locust beans fruit

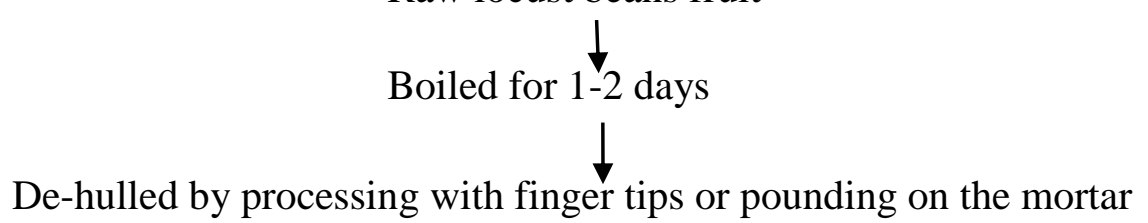

Washed and seed coat removed

Cotyledons boiled again for 1-2 hr

Cotyledons wrapped with pawpaw/ traditional leaves

Wrapped cotyledons packed in nylon

Fermentation for 5-6 days

Edible locust beans

Figure1: Channels in the Production of Edible Locust Beans

Source: Field survey, 2020

\section{Cost and Returns to Locust Beans Producers in the study Area}

Table 2 presents the cost and returns to locust beans producers in the study area. The producer made an average net income of $\$ 21,843.97$ at a selling price of $\$ 635.24$ with a capital turnover of 1.52. This implies that a producer will make a gain of 52 kobo on every invested on locust beans business in the area.

Table 2

\begin{tabular}{|c|c|c|}
\hline Items & Average Cost (N) & Percentage \\
\hline \multicolumn{3}{|l|}{ Variable items } \\
\hline Cost of harvesting & $8,880.78$ & 21.3 \\
\hline Cost of packing & $4,698.95$ & 11.3 \\
\hline Cost of boiling & $3,641.39$ & 8.7 \\
\hline Cost of de-hulling & $3,016.18$ & 7.2 \\
\hline Cost of washing and seed coat removal & $2,733.61$ & 6.6 \\
\hline Cost of wrapping in paper & $2,483.14$ & 6.0 \\
\hline Cost of wrapping nylon & $2,043.14$ & 4.9 \\
\hline Cost of fermentation and packaging & $2,530.25$ & 6.1 \\
\hline Cost of sales promotion & $3,960.71$ & 9.5 \\
\hline Total Variable Cost (TVC) & $33,988.15$ & 81.5 \\
\hline \multicolumn{3}{|l|}{ Fixed items } \\
\hline Depreciated cost of bucket & $1,943.33$ & 4.7 \\
\hline
\end{tabular}




\begin{tabular}{lll}
\hline Items & Average Cost (\#) & Percentage \\
\hline Variable items & & \\
Depreciated cost of steamer/pot & $4,508.62$ & 10.8 \\
Depreciated cost of sieves & 1,240 & 3.0 \\
Total Fixed Cost (TFC) & $\mathbf{7 , 6 9 1 . 9 5}$ & $\mathbf{1 8 . 5}$ \\
Total Cost (TC) & $\mathbf{4 1 , 6 8 0 . 1 0}$ & $\mathbf{1 0 0 . 0}$ \\
Revenue & & \\
Producers unit price (P) per kg & 635.24 & \\
Average quantity sold =100kg & & \\
Total revenue & $63,524.07$ & \\
Net income & $21,843.97$ & \\
Capital turnover (TR/TC) & $\mathbf{1 . 5 2}$ & \\
& Source: Field survey, 2020 \\
\end{tabular}

Source: Field survey, 2020

\section{Cost and Returns to Locust Beans Processor}

Table 3 presents the cost and returns to locust beans processors in the study area. The result revealed that the processor made a net income of $16,648.02$ at a selling price (processor price) of 946.90 per $\mathrm{kg}$ and a capital turnover of 1.21 . This implies that a processor will make a profit of 21 kobo on every 1 invested in the business in the area.

Table 3

Cost and Returns to Locust Beans Processor

\begin{tabular}{lll}
\hline Items & Average cost (N) & Percentage \\
\hline Variable items & & \\
Cost of unprocessed locust beans & 48965.52 & 62.74 \\
Cost of boiling & 6909.62 & 8.85 \\
Cost of de-hulling & 4128.65 & 5.29 \\
Cost of washing and removal of seed coat & 4582.21 & 5.87 \\
Cost of winnowing & 4208.65 & 5.39 \\
Cost of packaging & 2799.04 & 3.59 \\
Total variable cost & $\mathbf{7 1 5 8 9 . 6 9}$ & $\mathbf{9 1 . 7 3}$ \\
Fixed items & & \\
Depreciated cost of bucket & 1943.33 & 2.49 \\
Depreciated cost of steamer/pot & 4508.62 & 5.78 \\
Total fixed cost & $\mathbf{6 4 5 1 . 9 5}$ & 8.27 \\
Total cost (TC) & $\mathbf{7 8 , 0 4 1 . 6 4}$ & $\mathbf{1 0 0}$ \\
Revenue & & \\
Processors unit price (P) per kg & 946.90 & \\
Average quantity (Q) sold in $\mathrm{kg}=100 \mathrm{~kg}$ & & \\
Total Revenue (P x Q) & $94,689.66$ & \\
Net income (TR $-\mathrm{TC})$ & $16,648.02$ & \\
Capital turnover (TR/TC) & $\mathbf{1 . 2 1}$ & \\
\hline
\end{tabular}

Source: Field survey, 2020

\section{Cost and Returns to Locust Beans Marketer}

Table 4 presents the cost and returns to locust beans marketers in the study area. The result revealed that the marketer made a net income of $\$ 22,950.00$ at a selling price (marketer price) of $\$ 1,200.00$ per $\mathrm{kg}$ and a capital turnover of 1.24 . This implies that a marketer will make a profit of 24 kobo on every 1 invested in the business in the area. Comparatively, the three 
results indicated that the selling price of each category of the actors defers with the producers having the highest capital turnover of 1.52 .

Table 4

Cost and Returns to Locust Beans Marketers

\begin{tabular}{lll}
\hline Items & Average cost (\$) & Percentage \\
\hline Variable items & & \\
Purchasing cost & $88,000.00$ & 90.67 \\
Cost of family labour for miscellaneous operation & 1200.00 & 1.24 \\
Cost of storage & 1400.00 & 1.44 \\
Cost of transportation & $1,600.00$ & 1.65 \\
Cost of packaging & $1,500.00$ & 1.55 \\
Total Variable Cost (TVC) & $\mathbf{9 3 , 7 0 0 . 0 0}$ & $\mathbf{9 6 . 5 5}$ \\
Fixed items & & \\
Depreciated cost of bucket & 850.00 & 0.88 \\
Depreciated cost of sealing machine & $2,500.00$ & 2.57 \\
Total fixed cost (TFC) & $\mathbf{3 , 3 5 0 . 0 0}$ & $\mathbf{3 . 4 5}$ \\
Total cost (TC) & $\mathbf{9 7 , 0 5 0 . 0 0}$ & $\mathbf{1 0 0}$ \\
Revenue & & \\
Marketers unit price (P) per kg & $1,200.00$ & \\
Average quantity (Q) sold in kg $=100 \mathrm{~kg}$ & & \\
Total revenue (TR) = (P x Q) & $120,000.00$ & \\
Gross margin (TR - TVC) & $26,300.00$ & \\
Net income & $22,950.00$ & \\
Capital turnover (TR/TC) & 1.24 & \\
\hline
\end{tabular}

Source: Field survey, 2020

\section{Constraints Facing Locust Bean Actors (Producers, Processors and Marketers)}

Table 5 depicts the distribution of locust bean actors by major constraints in the study area. Result revealed that lack of modern technology which was the first and most severe problem of the producers and which constituted the $4^{\text {th }}$ constraints of the processor did not affect the marketer's category. Similarly, lack of capital which was attested to be the most militating problem of the processors, was the $3^{\text {rd }}$ and $4^{\text {th }}$ problems of the producers and marketers respectively. Poor storage facility was regarded as the $2^{\text {nd }}$ most militating problems of both the processors and marketers of locust bean in the area whereas the problem of lack of organised market which was considered as the most militating challenge of the marketers does not affect neither the producer nor the processor actor.

Table 5

Constraints Facing Locust Bean Actors in the Study Area.

\begin{tabular}{lllllll}
\hline \multirow{2}{*}{ Actors } & \multicolumn{2}{l}{ Producer } & \multicolumn{2}{l}{ Processor } & \multicolumn{2}{c}{ Marketer } \\
\hline Variables & Mean & Ranking & Mean & Ranking & Mean & Ranking \\
\hline Lack of modern technology & 2.67 & $1^{\text {st }}$ & 2.21 & $4^{\text {th }}$ & - & - \\
Climatic/ environmental problem & 2.54 & $2^{\text {nd }}$ & - & - & - & - \\
Lack of capital & 2.41 & $3^{\text {rd }}$ & 2.8 & $1^{\text {st }}$ & 2.34 & $4^{\text {th }}$ \\
\hline
\end{tabular}




\begin{tabular}{lcccccc}
\hline Actors & \multicolumn{3}{c}{ Producer } & \multicolumn{2}{c}{ Processor } & \multicolumn{2}{c}{ Marketer } \\
\hline Poor storage facility & 2.39 & $4^{\text {th }}$ & 2.27 & $2^{\text {nd }}$ & 2.55 & $2^{\text {nd }}$ \\
High cost of labour & 2.37 & $5^{\text {th }}$ & 2.13 & $5^{\text {th }}$ & - & - \\
High cost of transportation & 2.33 & $6^{\text {th }}$ & 2.10 & $6^{\text {th }}$ & - & - \\
High cost of machine & 2.14 & $7^{\text {th }}$ & 2.23 & $3^{\text {rd }}$ & - & - \\
Lack of organised market & - & - & - & - & 13.21 & $1^{\text {st }}$ \\
Lack of sales promoter & - & - & - & - & 2.48 & $3^{\text {rd }}$ \\
\hline
\end{tabular}

Source: Field survey, 2020

\section{CONCLUSION}

The study investigated the value addition of locust beans in Akoko Northwest Local Government Area of Ondo State, Nigeria. Result of analysed data from the 3 actors involved in the business indicated that majority of the actors were educated, married female with many years of experience and household size. The business had been proved to be profitable with the producers having the greatest benefit of capital turnover of 1.52 followed by the marketers who had a capital turnover of 1.24. The processors made the least financial benefit of 1.21 capital turnover in the business. It is also concluded that the degree at which the identified constraints such as lack of modern technology, lack of capital, poor storage facilities and lack of organized markets affects the actors defers from one category of the actor to the other.

\section{Recommendations}

The study recommends policies interventions that will promote quality locust bean production, equipping extension agents with the necessary materials that will stimulate extension education of the locust bean actors as well as provision of soft loans at reduced interest rate for locust bean actors. Training and retraining of practicing and intending locust bean actors is also recommended.

\section{References}

Adedokun A.A. (2006). Contributions of Locust Bean (Parkia biglobosa) Seeds Production and Marketing to the Household Economy of Kajola Local Government Area, Oyo State. B.S.c project Report. Department of Forest Resources Management, University of Ibadan. Ibadan, Nigeria. (Unpublished). Pp.13-14.

Adejumo, A.A. (2008). Processing, marketing and utilization of African locust bean (Parkia biglobosa, jacque benth) in Arigidi Akoko, Ondo State: implications for poverty reduction. A dissertation, Department of Forest Resources Management, University of Ibadan. $91 \mathrm{pp}$.

Babalola, F.D. (2012). Evaluation of the marketing chain of Parkia biglobosa (Jacq. Benth) R. Br. ex G. Don in southwest Nigeria. International Journal of Basic and Applied Sciences, 1(3), 210-217.

Campbell-Platt, G. (1980). African Locust Bean and its West African Fermented Food Products. Ecology of Food and Nutrient, 9, 123-132.

Douglas, S.J. (1996). Tree Crops for Food Storage and Cash Parts I and II World Corps, 24: 15-19, 86-132.

Eka, O.U. (1980). Effect of fermentation on the nutrient status of locust beans. Journal of Food Chemistry, 5, 305 - 308.

Musa, H.L. (1991). Ginger and Locust Bean Tree: History, Growth, Use and Potentials. Paper presented at Tuk Ham Symposium, Kurmin. 
Odunfa, S.A. (1981). Micro-organism Association with Fermented African Locust Bean during Iru preparation. Plant Food, 245-250.

Ojewumi, M.E., Omoleye, J.A. and Ajayi, A.A. (2016). The Study of the Effect of Moisture Content on the Biochemical Deterioration of Stored fermented Parkia biglobosa Seeds. Open Journal of Engineering Research and Technology, 1(1), 14-22.

Teklehaimanot, Z. (2004). Exploiting the potential of indigenous agroforestry trees: Parkia biglobosa and Vitellaria paradoxa in sub-Saharan Africa. Agroforestry Systems, 61-62, (1-3), 207-220. 